\title{
Petty Offences in Poland Between Criminal Law and Administrative Law
}

\section{Marek Kulik* Maciej Btotnicki*}

\author{
https://doi.org/10.31297/hkju.21.3.4 \\ UDK 343.232:342.922(438) \\ 343.192:342.922(438) \\ Review article / pregledni znanstveni rad \\ Received / primljeno: $\quad$ 19.2.2021. \\ Accepted / prihvaćeno: 25.6. 2021
}

This paper provides a commentary on the evolution and position of petty offence law in the Polish legal system. For the sake of order, it should be noted that the nature of petty offences is ambiguous and not one-dimensional. Their status and role depend on the assumptions of the legislator, who may emphasise their various aspects. A petty offence may be an element of criminal law in the broad sense, as a "small crime" or an administrative tort. More-

* Marek Kulik, Ph.D., Dr. Habil. Associate Professor, Maria Curie-Skłodowska University, Faculty of Law and Administration, Lublin, Poland (izvanredni profesor, Fakultet za pravo i upravu, Sveučilište Maria Curie-Skłodowska, Lublin, Poljska, e-mail: marek.kulik@ poczta.umcs.lublin.pl)

ORCID: https://orcid.org/0000-0003-0191-6558

** Maciej Błotnicki, PhD student, Maria Curie-Skłodowska University, assistant, Faculty of Law and Administration, Lublin, Poland (doktorski student, Fakultet za pravo i upravu, Sveučilište Maria Curie-Skłodowska, Lublin, Poljska, e-mail: maciej.blotnicki@ poczta.umcs.lublin.pl)

ORCID: https://orcid.org/0000-0002-1946-2606 
over, the development of Polish petty offence law and the arguments supporting the choice of specific legal solutions are presented. The probable future of Polish petty offence law was also indicated, aiming at the conclusion that the most serious petty offences would become crimes, and the rest would become administrative torts.

Keywords: petty offences, relationship between petty offence, crime and administrative tort, evolution of Polish petty offence law

\section{Introduction ${ }^{1}$}

The aim of this article is to present the basic features of Polish petty offence law from a historical perspective, against the background of the model of petty offence law developed in the German and Austrian doctrine, which has become an inspiration for Polish solutions, with reference to Swiss literature, where the mutual relationship between offences and administrative torts is similar to that in Poland. The study is limited to meta-legal issues, with little reference to procedural distinctions referring to particular forms of criminal acts within a criminal case. ${ }^{2}$ The evolution

1 The article is funded by the National Science Centre in Poland under the project "Reforma prawa wykroczeń" [The reform of petty offense law] No. UMO-2016/23/B/ HS5/03616.

2 Of course, there are distinctions in the procedural recognition of conduct (petty offence or administrative transgression). Their detailed analysis at the procedural level would pose the problem of ne bis in idem, which could be the subject of a separate study. Such attempts have been made many times in recent years, e.g. (see Luchtman, 2018, p. 1725; Lo Schiavo, 2018, p. 648) judgment of the ECtHR (Appl. Nos. 24130/11 and 29758/11) Strasbourg 16.11.2016; It should be borne in mind that the authors focused in the main part on substantive legal issues, treating the problem of ne bis in idem as secondary in relation to the whole issue. As a side note, it should be noted that recent case-law slightly changes the traditional approach to the ne bis in idem rule. In particular, attention should be drawn to the judgment of the ECtHR (Appl. Nos. 24130/11 and 29758/11) Strasbourg 16.11.2016. Admittedly, as we read in the grounds of that judgment, "the ne bis in idem principle is mainly concerned with due process, which is the object of Art. 6, and is less concerned with the substance of the criminal law than Art. 7", this or another understanding of it obviously affects the scope of the legal consequences borne by the convicted person. Undoubtedly, the recent case-law of the ECtHR does not fundamentally alter the standard that cases formally considered as administrative should be considered as criminal if they display the characteristics that the ECtHR pointed out in the Engel judgement (Appl. 5100/71; 5101/71; $5102 / 71 ; 5354 / 72 ; 5370 / 72$, Strasbourg 8.06.1976). This case-law, in particular the judgment 
of petty offence law in Polish law is the fundamental research problem of this study, presenting model assumptions. This analysis illustrates in sharp focus the problem of the relationship between petty offence and administrative tort. The characteristics of the Polish system, which will be presented in detail, made this problem general and systemic. The relationship between the categories of petty offence and administrative tort is not clear in principle. Even more so, it cannot be clear on the grounds of specific solutions. ${ }^{3}$ A specificity of Polish solutions is the fact that the area which in a number of European countries is occupied by administrative-criminal law or the law of petty offences, in Poland is managed by both of these categories appearing together. This specific situation is the result of historical development, which will be discussed later in this work. $^{4}$

in A and B vs Norway (Appl. Nos. 24130/11 and 29758/11), has resulted in a re-evaluation of the assessment criteria, what is "the same case" (Zolotukhin, Appl. 14939/03, Strasbourg 10. 02.2009). This is currently understood differently from the standard established by the Zolotukhin judgment. Without going into a detailed assessment of the judgment in A and B $v$ Norway, it is worth stating that the four criteria identified by the ECtHR, four substantive conditions which must be fulfilled for cumulative administrative and criminal penalties to be acceptable (proceedings pursuing complementary aims and addressing different aspects of the social misconduct at issue; foreseeability of the combination of penalties; no duplication of the collection and assessment of evidence; and an offsetting mechanism between the administrative and criminal penalties), do not substantially change the Engel standard. The ECtHR rightly states in its Engel judgment that "It is self-evident that there are criminal cases which do not carry any significant degree of stigma. There are clearly "criminal charges" of differing weight. What is more, the autonomous interpretation adopted by the Convention institutions of the notion of a "criminal charge" by applying the Engel criteria have underpinned a gradual broadening of the criminal head to cases not strictly belonging to the traditional categories of the criminal law, for example administrative penalties ..., prison disciplinary proceedings ..., customs law ..., competition law ..., and penalties imposed by a court with jurisdiction in financial matters .... Tax surcharges differ from the hard core of criminal law; consequently, the criminal-head guarantees will not necessarily apply with their full stringency."

${ }^{3}$ Therefore, the pandemic restrictions that have recently attracted the attention of the doctrine, although they are highly controversial, from a structural point of view do not bring anything new to the analysis of the issue. The scale of the pandemic restriction has renewed interest in the problem of the mutual relation between an offence and an administrative offence, but the pandemic regulations do not introduce any changes in the model approach. See e.g. the Act of 5 December 2008 on prevention and control of infections and infectious diseases in humans.

${ }^{4}$ This model is used in Switzerland, too (see e.g. Niggli \& Meader, 2011, p. 443; Jaag, 2010, p. 151). 


\section{Research Thesis}

The basic research thesis is the statement that Polish petty offence law has evolved from criminal-administrative law ${ }^{5}$ to a subcategory of criminal law, which has created an empty space, that was developed by repressive administrative law. ${ }^{6}$ This is the reason why in Polish law, apart from criminal law, there is law of petty offences and repressive administrative law, while in most European countries we are dealing with only one of them. However, it is factually unjustified and therefore should be changed. The source of this state of affairs is the specificity of the development of Polish petty offence law in the years 1928-1971, which determined its current shape. The evolution of petty offence law was preceded by an intensive scientific discussion, consciously referring to the arrangements of German literature. The deliberation led to the introduction in 1928 of the law of petty offences in the form that best reflected the legislator's sense. The regulations introduced in 1928 did not decree theoretical disputes, but allowed for various interpretations. However, they ensured on the one hand the efficiency of resolving cases, and on the other, a high level of guarantee. Nevertheless, further evolution of petty offence law was significantly influenced by political factors in the years 1945-1956. The legislator no longer avoided settling theoretical disputes, trying to directly shape petty offence law as a form of administrative law. After that period, as a reaction, there was a reversal of this concept. Consequently, the Code of Petty Offences of 1971, still in force today, made petty offence law a subcategory of criminal law. This procedure, however, generated an empty space in the place previously occupied by petty offence law. It was filled by administrative tort law, the existence of which generated additional theoretical and practical problems.

Polish petty offence law in its current form performs the same functions as administrative sanctions do in many European countries. On the other hand, in the Polish system there are also the above-mentioned administrative sanctions which perform the same role as everywhere else. This is

5 That is, from a model belonging to administrative law.

${ }^{6}$ This issue will be analysed in detail below. However, it is worth briefly explaining that criminal administrative law in the original sense given by Goldschmidt (1902) was in fact administrative law. This is also how the authors of the draft of the Polish petty offense law seemed to understand it (except for Rappaport - see below). Some doctrine still understands it this way, as will be discussed below. Meanwhile, this law has become a subcategory of criminal law. 
an atypical situation - apart from Poland, it still occurs in Switzerland, but nowhere else. ${ }^{7}$

The article uses the methods of historical - legal and formal - dogmatic research. References are made to the Polish and German literature on the subject, which was created during the shaping of the analysed regulations, concerning theoretical issues relevant to the topic, and to historical-legal and theoretical studies created nowadays.

\section{Discussion}

\subsection{Reflections on the Status of the Petty Offence}

In most European countries, repressive law in the broad sense usually consists of criminal law and criminal-administrative law, often referred to as petty offence law. The latter may be similar either to administrative or to criminal law. In this respect, Polish regulations are unusual. There is both petty offence law similar to criminal law, and repressive administrative law. A situation similar to that in Poland is found in Switzerland, where the Swiss doctrine, while acknowledging the existence of the problem, declares that it is actually difficult to determine the reasons for this situation (Niggli \& Meader, 2011, p. 443; Jaag, 2010, p. 151). In Poland this is the result of quite a long development.

Creation of the concept of modern petty offence law is traditionally associated with the words of Goldschmidt (1902). This is not entirely accurate, as there was already the so-called police law, performing the function of petty offence law (Schwander, 1952, p. 12; Eser, 1961, p. 16; Ohana, 2014, p. 12; Härter, 1999; Härter, 2007; Kulik, 2020, p. 93). However, it was Goldschmidt who introduced into the scientific debate the problem of the status of petty offence law, its relation to administrative and criminal law. The discussion that started with his speech continues in Germany to this day. Therefore, there are two main groups of positions. One includes the concepts that crime and offence differ only in seriousness (quantitative concepts) (Baumann, 1961;1972; Gürtler, 1990;2012; Jescheck, 1959; Krümpelmann, 1966, p. 166; Mattes, 1970; Müller, 2018,

7 This means, moreover, that Polish petty offense law can be compared in some respects both with criminal offences known in other European countries and with administrative penalties. 
p. 9; Müller-Dalhoff, 1993, p. 107; Theisen \& Vesper, 2010, p. 13). As a part of the second, which originates from Goldschmidt and his successors, in particular Schmidt (1949; 1948), there are qualitative differences between them (qualitative and quantitative-qualitative concepts) (Eser, 1961, p. 128; Cramer, 1971, p. 17; Rebmann, Roth \& Hermann, 1996, p. 10; Mitsch, 1995; Salem, 2009, p. 2; Bohnert, 2000).

The positions in the discussion that took place in Poland in the 1920s and 1930s were very similar. This consideration would probably have continued in the following years, if not for the events that followed World War II. These facts meant that while German petty offence law under the Gesetz über Ordnungswidrigkeiten of 1952 still entitles us to present both of these positions, Polish petty offence law may (compared to German criminal-administrative law) be considered as a form of "small criminal law" (Heine, 1999). The development of Polish petty offence law has gone from repressive administrative law to the subcategory of criminal law. As a result, an empty normative space appeared in the place previously occupied by criminal and administrative law, which was already filled. Over time, repressive administrative law developed alongside petty offence law. The debate in Germany on the concept of Goldschmidt coincided with the work on the systemic regulation of petty offence law in the Polish legal order, and it was reflected in the Polish discussion conducted in the years 1920-1939. The positions were polarised almost immediately (Lityński, 1991, pp. 56-57; Łysko, 2016, p. 26; Skupiński, 1974, p. 76; Marek, 1967). According to Juliusz Makarewicz, the chairman of the Criminal Law Codification Committee, liability for administrative breach should qualitatively differ from criminal liability. Following Goldschmidt, he assumed that crime is a direct attack on the subject of protection, and a petty offence is a disobedience to legal order. Therefore, responsibility for them is a form of administrative responsibility (Makarewicz, 1920, Powrotna; Makarewicz, 1924, p. 6; Makarewicz, 1920, Granice). Another member of the Committee, Rappaport, presented a view similar to that expressed in Germany by the most serious critics of Goldschmidt's concept: Beling (1891) and Frank (1897, p. 18; 1905). He argued that between criminal law and petty offence law there is no qualitative difference, but a quantitative one - they differ in the level of criminal reprehensibility. However, for practical reasons, he considered it was necessary to relieve the courts from examining cases of breach of order, or at least some of them. He suggested dividing administrative torts into more serious and minor ones. The former would not only be directly related to specific fields of administration's activity but also punishable by arrest. 
These cases would be examined by criminal courts. The latter acts, concerning specific forms of administrative activity, would be examined by administrative authorities (Rappaport, 1919).

Basically, this discussion has not been settled. The legislator did not decide it either. The Constitution of the Republic of Poland of 1921 provided that everyone had the right to a fair trial (Art. 98). Nevertheless, it also stipulated in Art. 72 that criminal matters could also be adjudicated by administrative authorities under judicial control. Therefore, the fact that the Act of 22 March 1928 on criminal-administrative proceedings referred the jurisprudence to administrative authorities, did not prejudge the nature of petty offence law. Likewise, it was not determined by the regulation of the President of the Republic of Poland of 11 July 1932, the Act on Petty Offences, which shaped liability for a petty offence similar to administrative liability, but with significant elements making it similar to criminal responsibility (Jakubowska-Hara, 2004, p. 8; Łysko, 2016, p. 26-27). It was a compromise solution, yet closer to the dualistic concept of Rappaport than to the penal-administrative structure of Makarewicz (Kulik, 2020, p. 139).

The discussion lasted until the outbreak of World War II and was briefly resumed after its end. Most often, crime and petty offences were perceived as acts of a similar nature - the difference between them was not seen as qualitative, but a quantitative one (Glaser \& Mogilnicki, 1934, p. 54; Makowski, 1937, p. 64; Bojarski, 1990), yet there were also well-founded different views (Wolter, 1947, p. 76).

\subsection{A Discussion of the Status of Petty Offence During the Formative Years of Real Socialism in Poland}

After the end of the war, this discussion had to take place in diametrically changed socio-political conditions. A new view of the political authorities appeared on the role of law and the judiciary. While the pre-war legislator tried to avoid resolving theoretical and legal problems, the post-war legislator considered it necessary. It was assumed that the judicature in cases of petty offences is a tool for the implementation of the educational tasks of the administration, when criminal law is used to fight the class enemy (Zimmermann, 1956, p. 420; Mieńszagin \& Wyszyńska, 1953, p. 11). ${ }^{8}$ Based

\footnotetext{
8 It is interestingly analysed by Łysko today (2016, p. 35).
} 
on this assumption, there was official support for a kind of simplified qualitative concept (Bachrach, 1953, p. 32; Rajkowski, 1955, p. 62; Litwin, 1955; Rybicki, 1956; Mieńszagin \& Wyszyńska, 1953, p. 11). ${ }^{9}$ However, its promotion by the authorities was to cause distrust of Polish theorists in any qualitative approach in the future. ${ }^{10}$

Initially, voices critical of qualitative concepts were rare. Only Iserzon argued that not only a crime, but also a petty offence, violates the interests of the ruling class, so there is no reason to regard them as different entities (Iserzon, 1959).

Until 1956, qualitative approaches influenced the shape of the legislation. The main effect of their application was that while criminal law was strict and became more and more severe, the petty offence law between 1944 and 1956 definitely softened (Lityński, 2010, p. 7). Petty offence law, while playing an educational role, could be mild. It was supposed to implement the so-called concept of democratic upbringing - to eliminate "anti-social individuality" and selfishness, which were considered to be partly innate and partly caused by improper upbringing in the conditions of traditional society. It was supposed to support the creation of a socialised, pro-socially oriented person (Klaus, 2013).

On the other hand, a reverse tendency was noticeable, resulting from the efforts to simplify the procedure in matters considered important for the existence of state. A whole range of behaviours, which should be considered as criminal offences due to the importance and subject matter of protection, were formally moved beyond criminal law (Marek, 1996, p. 27). ${ }^{11}$ They were prosecuted under the administrative procedure provided for in the Act of 15 December 1951 on criminal-administrative judgments. Extrajudicial bodies adjudicated in administrative proceedings (Jastrzębski, 1956; Daręgowski, 1959; Lewiński, 1977, p. 3; Łysko, 2016; Łysko, 2016, p. 37), created in a similar way as criminal proceedings, but without judicial control, typical of pre-war solutions.

After 1956 (the period of the so-called "thaw"), there was general leniency of criminal law, but a stricter punishment for petty offences. This

${ }^{9}$ What draws attention in particular is the view of W. Mieńszagin and Z. Wyszyńska, which contradicts the principles of common sense, that the difference between criminal law and petty offense law arose from the fact that the quantitative difference between them (the level of social danger of an act) was so large that it became a qualitative difference.

${ }^{10}$ It is noted by Łysko (2016, p. 38).

11 Structurally, this solution was similar to the Austrian one. 
was expressed in the amendment to the Act on criminal-administrative judgments in 1958 (Łysko, 2017), which, at the same time, reduced the very extensive structure of penal-administrative judgments (Łysko, 2016).

In the literature, the opinion that petty offence law belongs to the broadly understood criminal law gained advantage (Dąbrowski, 1967; Sziszow, 1961;12 Dąbrowski, 1970, p. 34; Rybicki \& Sobczak, 1957), which meant that it was no longer considered a purely educational area of law. It did not have to be as gentle as it had been before. The "thaw" also opened the way for a serious discussion on what exactly petty offence law is and how it should be shaped for the future. There were several important theoretical statements, which were dominated by an aversion to qualitative views, discredited during the Stalinist period. Extremely important for the future of the Polish petty offence law was the statement by an outstanding dogmatist of the new generation, Kubicki, who explicitly stated that petty offence law was nothing else than the remnants of criminal law that did not fit into the Criminal Code (Kubicki, 1961, p. 501). At the same time, there was a well-established view of the appropriateness of the solution consisting in maintaining the division of criminal offences into misdemeanours and crimes. There was no intention to introduce a third category of criminal offences, which resulted in the appearance of petty offences as a quasi-crime, outside of the strict criminal law, but within criminal law in the broad sense (Andrejew, 1955; Jakubowska-Hara, 2004, p. 82; Łysko, 2016, pp. 45-46).

A fierce dispute over the desired status of a petty offence continued in the course of work on the 1971 Code of Petty Offences. There were conflicting views within the working group that a petty offence was an administrative lawlessness (Lenieli, 1961) or that it was a form of criminal law (Kubicki, 1961, pp. 498-499; Iserzon, 1961). This has led to a state of petty offence law having characteristics that can be linked more to criminal law than to administrative law. The decision to suspend work on the Code of Petty Offences until the Penal Code of 1969 was drafted. It was indicated as the final victory for the concept of the affiliation of petty offence law with the broadly understood criminal law. Only then was the work on the 1971 Code of Petty Offences completed (Jakubowska-Hara, 2004, p. 58; Łysko, 2015).

The passage of the bill of 17 June 1966 was an important factor in the transfer of certain minor offences as petty offences to criminal-adminis-

12 See the contemporary analysis by Łysko (2016, p. 45). 
trative judgments. It was an expression of the tendency to transform minor crimes into petty offences, which was further deepened by the Code of Petty Offences of 1971 (Marek, 1996, p. 26). The transfer of numerous criminal offences to the category of petty offences made it nearly impossible to perceive petty offence law as law of breach of order.

\subsection{The Formation of the Relationship of Petty Offence Law to Administrative-Criminal Law}

Therefore, the view of a purely qualitative difference between petty offence law and criminal law is no longer present in the modern doctrine. It either takes the position that petty offence law is a hybrid of criminal and administrative law (Kubicki, 1961, p. 501; Budyn-Kulik, 2012), or it is considered to be a separate area of criminal law in the broad sense (Gostyński, 1982, p. 13; Radecki, 2009; Marek, 2010; Vachev, 2016). The status of a petty offence as a being functioning between administrative law and criminal law could not be changed by subsequent amendments to petty offence law. The criminal law component of the petty offence was strengthened by the transfer of adjudication in these cases to courts, which took place in 2001.

Eventually, it must be admitted that Polish petty offence law, at least to some extent, is "small criminal law", and numerous petty offences are "small crimes" (Budyn-Kulik, 2017). The solution adopted by the Polish legislator generated many tangential areas requiring resolution. For example, theft of things up to PLN 500 is basically known as a petty offence, and above this value it is a crime. This rather strange status of Polish petty offence law has two different effects. The first is the one mentioned by Vachev - it is impossible to look at Polish petty offence law as a homogeneous structure, and thus it is impossible to provide criteria that would qualitatively characterise an offence - apart from a purely formal reference to the statutory definition of a petty offence. The second effect is the one that Marek writes about - since it is not known how to qualitatively characterise a petty offense, because it is both criminal and administrative tort, it is not known how it differs from a crime (Marek, 2010, p. 33). Therefore, there are no criteria which should be followed by the legislator when describing an act as a crime or a petty offence.

However, the evolution that Polish petty offence law has undergone from order law to small criminal law, has generated an empty space there was no order law in the strict sense. That is why repressive adminis- 
trative law appeared. The first case of such liability was introduced by the decree of 28 January 1953 on securing the rational and economical use of electricity and heat. Originally, liability for an administrative tort could only be assumed by legal persons (Radecki, 2019, pp. 30-31), and this was a feature that differentiated criminal liability (for a criminal offence or petty offence) from administrative tort liability. The doctrine usually assumed that it is a kind of administrative responsibility (Domański, 1976; Wolter, 1973). With time, it became possible to bring people to administrative tort liability, which meant that the clear line between the spheres reserved for administrative and criminal liability was blurred. This is how a separate form of responsibility appeared, which Szumiło-Kulczycka aptly called administrative-criminal liability. The author distinguished this form of liability from criminal liability, which is liability for a crime, and which in the course of evolution became liability for a petty offence (Szumiło-Kulczycka, 2004, p. 29). Most authors consider it formally as a sub-category of administrative liability (Domański, 1976; Wolter, 1973), but in fact it has many features of criminal responsibility. This is an expression of a general tendency, sometimes referred to as the conversion of criminal liability into repressive administrative responsibility (Danecka, 2018, p. 50). Currently, the status of this type of liability is the subject of intense discussion in Polish literature, while representatives of the doctrine of administrative law usually regard it as a form of administrative liability (Błachucki, 2015), ${ }^{13}$ and representatives of the doctrine of penal law - as a form of liability, if not criminal, then a repressive one (Skupiński, 2003; Kmieciak, 1997; Wróbel, 2011; Mozgawa \& Kulik, 2016). Also, in the judicature of the Constitutional Tribunal, it is assumed that the ne bis in idem rule must be applied to the concurrence of criminal liability and administrative tort liability, ${ }^{14}$ following the judicature of the ECtHR. ${ }^{15}$

13 Speaks in a similar way: Stahl, 2011, p. 18.

14 E.g. judgment of the Constitutional Tribunal, (K 17/97), Warsaw, 29.4.1998; judgment of the Constitutional Tribunal, (P 26/06), Warsaw, 15.4.2008; judgment of the Constitutional Tribunal, (P 29/09), Warsaw, 18.11.2010; judgment of the Supreme Court, (I KZP 27/08), Warsaw, 17.12.2008.

15 E.g. judgment of the ECtHR, (5100/71), Strasbourg, 8.6.1976; judgment of the ECtHR, (9912/82), Strasbourg, 25.8.1987; judgment of the ECtHR (11034/84), Strasbourg, 22.5.1990; judgment of the ECtHR, (18996/91), Strasbourg, 24.8.1997. See also Gullikson, 2015 p. 143; Bailleux, 2014, p. 139. 


\subsection{Doubts about the Current Shape and Relationship of Petty Offence Law to Administrative-Criminal Law}

Thus, Polish law currently knows three categories of criminal acts - crimes, petty offences, and administrative torts. The first two give rise to criminal liability (Radecki, 1994; Radecki, 2014; Danecka, 2018, p. 35; Błachnio-Parzych, 2016). The status of administrative tort liability is not clear. As it is known, on the basis of Art. 6 of the ECtHR, cases for acts that are administrative torts under Polish law, among others, can be considered as criminal cases. The formal classification of the act is preselective and does not prejudge anything. It is important whether the sanction is general and abstract, what norm imposes it, whether responsibility depends on guilt, and finally, whether it is possible to impose a penalty of deprivation of liberty. ${ }^{16}$ On the other hand, the Polish legislator does not always attach importance to respecting the division of law into branches, which means that there may be cases when a legal act does not fall within a single field of law (Kruk, 2013, p. 149). This is relevant to the issue under analysis (Mozgawa \& Kulik, 2016, p. 38).

The Polish Constitutional Court considers tort administrative liability as criminal liability in the constitutional sense. Therefore, it accepts the necessity of applying the ne bis in idem rule to cases of concurrence of criminal liability and administrative tort liability ${ }^{17}$ (Daniluk, 2010; Król-Bogomilska, 2012). The historical development of Polish criminal offence law and repressive administrative law presented above convinces that the difference between a criminal act and an administrative tort can be quite easily perceived in the formal sense. In the substantive sense, not only a case of a crime or a petty offence, but also a case of an administrative tort as it is defined in Polish law should be considered as a criminal case.

However, in the Polish doctrine of administrative law, most often responsibility for an administrative tort is considered administrative. It is assumed that the administrative sanction, also repressive, is natural, and the intensity of administrative repression is only apparent. It reflects the threat posed by the violation of administrative regulations. It is an expres-

16 Judgment of the ECtHR (14939/03), Strasbourg, 10.2.2009; judgment of the ECtHR (7819/77), Strasbourg, 10.2.1984; judgment of the ECtHR (9912/82), Strasbourg, 28.6.1987.

17 Judgment of the Constitutional Tribunal, (P 26/06), Warsaw, 15.04.2008; judgment of the Constitutional Tribunal, (P 29/09), Warsaw, 18.11.2010; judgment of the Supreme Court, (I KZP 27/08), Warsaw, 17.12.2008 
sion of special protection of public interest, and its amount is adapted to the material situation of the addressees of norms and the intensity of the violation of public interest (Błachucki, 2015). It is worth noting critically that administrative torts often concern matters not directly related to the process of administration, and they operate with a sanction so onerous that it is difficult to imagine the possibility of imposing it in a state governed by the rule of law other than in a process that ensures impartial examination of the case by a court adjudicating on a fault basis (Wierzbowski, 2005; Kulik, 2020, p. 139; Szumiło-Kulczycka, 2004, p. 26).

It is the reliance on the principle of guilt and the existence of sentencing principles that are the essential features of criminal punishment. Danecka expresses the position that in some (rare) cases of administrative responsibility it is possible to see some elements of guilt (Danecka, 2018, p. 35). In turn, a substitute for the principles of penalty assessment was introduced into the Code of Administrative Procedure by the Act of 7 April 2017 amending the Act-Code of Administrative Procedure and some other acts in the form of Section IVa on administrative fines. Art. $189 \mathrm{~b}$ of the Polish Administrative Procedure Code (KPA) provides that an administrative fine is a pecuniary sanction imposed by a public administration body by way of a decision as a result of a violation of law involving a failure to comply with an obligation or a breach of a prohibition imposed on a natural person, a legal person, or an organisational unit without legal personality. Further provisions deal with the conflict of laws in time, the principles of penalty assessment, exclusion of liability due to force majeure, cases of waiver of punishment, the statute of limitations, and mitigation of penalties.

This regulation introduces a criminal law element to administrative regulation, but it is criticised as not being sufficiently guaranteeive (Danecka, 2018, p. 116). It also gives no indication of what repressive administrative liability is (Kulik, 2020, p. 159), although the way it is regulated indicates that formally it is something different from criminal liability. It is usually not based on the principle of guilt, and it is ruled by an administrative body rather than a court (Stankiewicz, 2017). In the formal sense, it is administrative responsibility, but in the Polish doctrine the very understanding of administrative responsibility and its general criteria are not clear (Filipek, 1963; Wincenciak, 2008; Stankiewicz, 2017). Sometimes it is even assumed that it is such a responsibility that is neither criminal nor civil (Kwaśnicka, 2011). This is an insufficient approach (Kulik, 2020, p. 161). It is much better to talk about linking the sanction to the non-performance of an obligation imposed by the administrative body (Lewicki, 
2002; Wincenciak, 2008; Szydło, 2003; Kruk, 2013, p. 110). Determining the limits of administrative responsibility involves defining its fundamental purpose, which coincides with the purpose of public administration (Stefaniuk, 2009; Kruk, 2013, p. 109). Secondly, in the analysed case it is about this form of administrative responsibility, which is connected with the application of administrative coercion (Kruk, 2009).

Undoubtedly, both in the case of criminal law and administrative law, responsibility arises from the violation of the law (Wincenciak, 2008; Stelmasiak, 1993). Those who write that the purpose of repressive administrative law is to ensure respect for the law, and the purpose of criminal law is only repression, are wrong (Kruk, 2013, p. 109; Starzyński, 2013; Ušak, 2010). After all, the purpose of criminal law is, among others, prevention (Mozgawa \& Kulik 2016, p. 41; Danecka, 2018, p. 49), whereby prevention is best realised by liability based on the principle of guilt (Danecka, 2018, p. 36; Kulik. 2020, p. 161). Criminal law is repressive in nature, but the same can be said of administrative tort law. Both operate a nuisance as a sanction (Szumiło-Kulczycka, 2004, p. 26). Wincenciak rightly notes that the method of regulation used in repressive administrative law is essentially criminal law - a prohibition is created, and its violation is subject to a repressive sanction (Wincenciak, 2008). The view that since criminal penalties are imposed by the court, and administrative penalties by a non-judicial body, the latter are not the administration of criminal justice is not convincing (Nowicki \& Peszkowski, 2016). Also, the view that there is always a difference between criminal and administrative sanctions in terms of severity is not accurate, since administrative law operates only with a financial penalty, and criminal law also with sanctions that violate civil liberties and rights (Nowicki \& Peszkowski 2016). Modern criminal law operates very extensively with fines, and administrative fines can be extremely harsh.

Wierzbowski is quite right when he writes that an administrative sanction should not be repressive in nature but should consist of enforcement, nullity, or possibly compensation (Wierzbowski, 2005). However, as Zimmermann wrote, if administrative acts are to be truly effective, they must contain sanctions. If an administrative body had no means to carry out its will, administration would be impossible (Zimmermann, 1956, p. 400). In other words, administrative sanctions serve the efficiency of administration (Danecka, 2018, p. 114). In this sense, an administrative sanction in the form of a fine is a necessary tool of administrative law (Szydło, 2003; Michór, 2009; Kulik, 2020, p. 164). Classical administrative law operates admittedly different types of sanctions: enforcement (which sometimes 
take the form of penalties to compel behaviour consistent with the demands of the authority), sanctions depriving or limiting the right, concession, permit, or consent (Wincenciak, 2008). This set of sanctions was sufficient in classical administrative law (Longchamps, 1967), but nowadays the administrative monetary "penalty" is an effective tool of administrative coercion (Nowicki \& Peszkowski, 2016).

Therefore, not all cases of repressive administrative liability should be considered as part of criminal law. Since we are talking about a repressive sanction, a criminal law factor in the constitutional sense will always be present here. This does not mean that there cannot be an administrative element, which allows the perception of a repressive administrative sanction as an acceptable and desirable entity on the grounds of administrative law. This is determined by what has often been forgotten in the course of the historical development of the Polish petty offence law and administrative repressive law - ratio legis of responsibility (Malanowski, 2009). In the case of administrative tort liability, ratio legis is to ensure the proper exercise of authority by administrative bodies. Nowicki and Peszkowski aptly write that while criminal penalties are imposed for fundamental violations of the principles concerning the coexistence of people in the community, administrative penalties sanction violations of norms that are often technical in nature and are an additional means used by the administration to enforce laws (Nowicki \& Peszkowski, 2016). Thus, where the violation of certain protected goods is directly involved, criminal law steps in. Where it is a question of violating the quality of the process of administration - liability for administrative tort comes into play. This does not mean that administrative tort law is not concerned with the protection of legal goods, since the process of administration is intended to achieve goals that are beneficial to the state (Frank, 1897, p. 18). The moral reprehensibility of administrative tort stems from the fact that it impedes administration, which is intended to be beneficial to the community.

\subsection{Relation of the Polish Legal State to Theoretical Models of Criminal-Administrative Responsibility}

The above approach shows some similarity to certain quantitative and qualitative German concepts. To some extent, it is similar to Schmidt's model of sozialetische Unrechtbewertung. According to him, the substantive lawlessness of a crime manifests itself in the violation or endangerment of the sphere of interests of social life. It is based on the violation of some moral 
value, when in the case of a petty offence only the interest of maintaining order is violated and not the interest of the possessor of some concrete object of protection (Schmidt, 1949, p. 230). Unlike Schmidt, we believe that this does not mean that there is no assault on a legal good in the case of an orderly transgression. All violations of legal norms in some sense are such an attack. Thus, this view is closer to the position of Eser, who believes that crimes should be acts that attack a legal good in a manner proportional to the punishment provided for them by law, and petty offences should be acts that violate orderly social norms, for which the law provides protection (Eser, 1961). It may be added that in the case of a breach of order, the protected good appears in the further background - these are the values protected by proper administration (Kulik, 2020, p. 172).

The above distinction may seem quite clear at first glance. However, this is so only if one considers the pure model itself, and thus purely theoretically. When making such distinctions, it is relatively easy to make pure model distinctions. This is what has characterised the approaches presented in the German or Austrian literature over the years. In each case, an attempt was made to make a clear distinction not on the basis of some real legal state, but on the basis of some imaginary world, which is an image of some conceivable reality.

This, it should be strongly emphasised, is a significant advantage of such an approach. Operating on any existing legal state, the researcher inevitably gets entangled in a number of circumstances that obscure the picture, thus making it impossible to develop models of responsibility. Departing from the existing legal state, we have the opportunity to create a potentially correct construction, because it is not burdened by various backgrounds. It is worth emphasising that the construction of Goldschmidt, cited at the beginning, was not created in a social reality in which administrative-criminal law, or police law, did not exist. Such law did exist. German states have long had a category of police misconduct alongside criminal offences, regulated by laws of an administrative nature. At first, the existence of such regulations was not associated with theoretical reflection on them. Besides, the relation of this police lawlessness to criminal lawlessness was not clear for a long time. It can even be argued that police lawlessness simply included the most minor crimes, and that it was included in criminal law in a broad sense, recognising the criminal law nature of police transgression, although - which should be emphasised liability was formally of an administrative nature. Relatively quickly there were attempts to theoretically master the normative reality that had been found. Feuerbach was already of the opinion that in the case of a crime, 
we are dealing with behaviour that directly violates human law. Where this right is not attacked, we can only deal with police lawlessness. In this sense, substantively, a police tort is simply an administrative violation for which the state uses a punishment shaped like a criminal one, albeit a milder one. This concept is worth remembering if only because the underlying idea for solving the problem of the status of police law is not very far from what Goldschmidt later proposed (Feuerbach, 1801; 1822). However, what Feuerbach, and shortly after him Köstlin, proposed in arguing that crime constitutes real lawlessness (wirkliches Unrecht), and police transgression is potential lawlessness (mögliches Unrecht) (Köstlin, 1845), was a brilliant conception of mastery over the existing world. In making this attempt, neither Feuerbach nor Köstlin faced any pressing intellectual need to master normative phenomena. The description thus included a diagnosis of the normative status of the law of order, but did not involve an attempt to shape it.

In contrast, Goldschmidt's concept was the idea of creating a model of an imagined normative reality that could be arranged according to some preconceived rational pattern. A very similar task would be undertaken several decades later by Schmidt, constructing the assumptions of German petty offence law after World War II. The same task was faced by Rappaport and Makarewicz while constructing the assumptions of petty offence law in the first years of independent Poland, as well as by the authors of the Polish Code of Petty Offence of 1971.

The social situations in which a complete re-evaluation of thinking about criminal-administrative responsibility was carried out show a certain similarity. In all of these cases, there was a huge expansion of repressive administrative legislation, and they were usually undertaken in a very particular social situation. Neither Feuerbach nor Köstlin had to make assumptions about a system of administrative law. Police law regulations in their time existed, expanded, but did not pose a great normative problem because they did not enter the territory traditionally reserved for criminal law, and moreover, the scale of their operation was not great.

It was different in the case of the attempts at a systematic development of petty offence law made by Goldschmidt, Schmidt, Polish codifiers of the 1930s, and then of the 1960s. In all these cases, there was a great development of administrative-criminal law, which replaced criminal law. In German literature it is noted that the period from 1871 to 1914 was associated with a rapid arrival of non-code laws, which from the theoretical point of view could not be classified unambiguously as criminal or administrative law, which blurred the distinction between criminal and 
administrative law. It was significant that some laws introduced a regulation, according to which the proper procedure was an administrative proceeding, but at the request of the offender the case was heard by the court in criminal proceedings (Bohnert, 2000). These regulations were therefore actually criminal-administrative hybrids.

It should be added that they concerned cases of various degrees of complexity, sometimes quite serious. It was on the basis of such a legal state that Goldschmidt's concept appeared. Significant for the further development of criminal, administrative, and administrative-criminal law was the legislation of the years 1933-1945, which was characterised by a largescale replacement of classical criminal regulations with typical administrative regulations, especially in the area of protection of the economic market. This was the classical law of war (not unlike the years 1871-1914) (Ohana, 2014, p. 18). Besides, also in the period just after World War II, there was no quick departure in Germany from the wide replacement of classical criminal law regulations by administrative, quasi-administrative, or perhaps quasi-criminal regulations. This was fostered by the need to run the economy in the conditions of the post-war crisis on non-market principles (Schmidt, 1948). Under such conditions, the reflection on the status of administrative-criminal law was undertaken by Schmidt. Makarewicz and Rappaport worked in the period after World War I, moreover, in a legal state largely shaped by the war economy - identically to Goldschmidt and Schmidt. Also, the systemic reflection undertaken on the status of petty offence law in the 1960s took place in a situation in which there was a dogmatically and axiologically questionable confusion between criminal law and administrative law (Łysko, 2020).

It is easy to see that periods of significant intensification of a crisis of some kind bring about the need to rethink the assumptions of the system itself. There are many indications that this is exactly the situation we are dealing with now. Danecka rightly writes that nowadays in Poland, repressive administrative law more and more often simply performs the functions of criminal law (Danecka, 2018, p. 115). In a sense, we are dealing here with pure interchangeability. A notable example is the Act of 22 June 2017 amending the Act on the protection and care of historical monuments and some other acts, which simply transformed a number of offences contained therein into administrative torts - in principle without any major changes in the content of the prohibition (Gadecki, 2018). This is not the only case of the occurrence of administrative law in the role of petty offence or criminal law, but this is a special example - petty offences were directly transformed into administrative torts. 
It seems that the development of Polish petty offence law and the emergence, independently from it, of repressive administrative law caused a certain imbalance in proportions between the protection of legal goods (the domain of criminal law) and the protection of the process of proper administration (the domain of petty offence law or administrative-criminal law). In the course of evolution, acts which, because of their seriousness and directness in harming legal goods other than the correctness of administration, should be criminal offences, became petty offences. For this reason, petty offences took on the characteristics of crimes, while the empty space (protection of the process of administration) was occupied by administrative torts. They are now fulfilling the role originally performed by the acts prohibited as petty offences. As indicated above - Polish petty offence law was originally conceived as a form of repressive administrative law, but in the course of development it acquired features of criminal law relating to minor law infringements. For both reasons, repressive administrative liability de lege lata is becoming less and less different from criminal liability in the broad sense, i.e. criminal law in the narrow sense and petty offence law. It should be added that this approximation concerns criminalisation in the material sense. In the procedural sense, we are still dealing with different procedures. It is not unimportant for the addressee of the norm that in the case of an administrative tort his case is decided by an administrative body with subsequent judicial review, whereas in classic criminal proceedings, of which the petty offence proceedings are a variant, his case would be decided by a court and he would be entitled to the right of defence.

However, de lege ferenda it can be postulated that these are cases of responsibility serving different purposes. It may be assumed that repressive administrative liability comes into play in cases that are directly related to ensuring the regularity of administration (Kruk, 2009, p. 109; Kulik, 2020, p. 176), but not in all cases. It should not be allowed for acts characterised by a significant level of social harm. These should be crimes (Kulik, 2020, p. 179). This view is voiced with the awareness that nowadays repressive administrative sanctions are characterised by great expansiveness - they often replace criminal law, also where it is not substantively justified (Danecka, 2018, p. 115).

\section{Conclusion}

The above statement makes sense when we talk about distinguishing repressive administrative responsibility from criminal law in the broad sense, i.e. in the current legal state in Poland - from criminal law in the 
narrow sense and petty offence law. Distinguishing petty offence law from criminal law on the one hand, and from repressive administrative law on the other hand is impossible. This is justified by the fact that petty offence law in its present form contains both clearly criminal acts and administrative torts (Marek, 2010, p. 33). This state of affairs leads to the conclusion that it is possible to distinguish two branches whose general assumptions are more or less clear. These are: criminal law and administrative tort law. Petty offence law in its present form is a kind of normative neoplasm, shaped by years of differently directed changes. If an attempt were made to determine what it actually is, one would have to admit that historical evolution has brought it to a state in which it can be regarded as criminal law par excellence, with some relict features of responsibility for a public order offence (Kulik, 2020, p. 181). It seems that such a hybrid is not at all necessary. It does not fill any empty space between criminal law and repressive administrative law, as they interpenetrate despite its existence. The original purpose of the existence of petty offence law was to cover the criminalisation of acts of order. This role is fulfilled today by repressive administrative law. Petty offence law evolved in Poland in such a way that it started to duplicate criminal law and administrative repressive law. But the starting point - as mentioned at the beginning of the paper - was that petty offence law was called repressive administrative responsibility. Petty offence law was not to exist alongside such liability, as it does today, but was simply to be it. No one imagined a legal state in which there is liability for a petty offence and liability for an administrative tort that is not a petty offence. Rappaport, perceiving a petty offence as a form of crime, was still moving in the sphere of treating the category of administrative offences he had distinguished as violations related to the sphere of administrative activity, and thus in the sphere of responsibility shaped in a manner similar to modern administrative torts, less to petty offences (Rappaport, 1919).

The above seems to imply that from the very idea of liability for a petty offence, it was originally, and perhaps should continue to be - an order responsibility, which would be decided by an administrative body, obviously under judicial control. It is probably no coincidence that the process of making petty offences more similar to crimes occurred in conjunction with the process of forming independent administrative responsibility of a repressive nature. Perhaps the most effective reform of petty offence law would therefore be its liquidation, combined with the transformation into misdemeanour of those acts that are clearly criminal in nature, and therefore do not directly affect the functioning of the administrative pro- 
cess, while their level of social harmfulness is high. Other petty offences, i.e. minor offences affecting the proper functioning of the administrative process, should be converted into administrative torts.

\section{References}

Andrejew, I. (1955). Przyczynek do trójpodziału przestępstw [A contribution to the tripartition of crimes]. Panstwo i Prawo, 12, 885-902.

Bachrach, A. (1953). Niektóre zagadnienia procesu karnego w świetle Konstytucji. Z praktyki i teorii procesowej $w$ latach 1945-1952 [Some issues of criminal trial in the light of the Constitution. From practice and procedural theory in the years 19451952]. Warsaw, Poland: Wydawnictwo Prawnicze.

Bailleux, A. (2014). The fiftieth shade of grey. Competition law, "criministrative law" and "fairly fair trials". In F. Galli \& A. Weyembergh (Eds.), Do labels still matter? Blurring boundaries between administrative and criminal law. The influence of the UE (pp. 137-152). Bruxelles, Belgium: Editions de l'Université de Bruxelles.

Baumann, J. (1972). Über die notwendigen Veränderungen im Bereich des Vermögensschutzes. [On the necessary changes in the area of asset protection]. Juristenzeitung, (27), 1-6.

Baumann, J. (1961). Zum Teilbarkeit des Unrechtsbewußtseins. Kritische Bemerkungen zum Urteil des BGH v. 28.2.61, 1 StR 467/60 [On the divisibility of the consciousness of wrongdoing. Critical comments on the judgement of the Federal Supreme Court of Justice of 28.2.61, 1 StR 467/60]. Juristenzeitung, 18, 564-566.

Beling, E. (1891). Der amliche Entwurf eines allgemeinen deutschen Strafgesetzbuchs [The official draft of a general German criminal code]. Gerichtsaal, 1, 348377.

Błachnio-Parzych, A. (2016). Zbieg odpowiedzialności karnej i administracyjno karnej jako zbieg reżimów odpowiedzialności represyjnej [The concurrence of criminal and administrative/criminal liability as the concurrence of regimes of repressive liability]. Warsaw, Poland: Wolters Kluwer Polska, https://doi.org/10.18794/ aams/109981

Błachucki, M. (2015). Wstęp [Introduction]. In M. Błachucki (Ed.), Administracyjne kary pieniężne $w$ demokratycznym panstwie prawa [Administrative fines in a democratic state under the rule of law] (pp. 5-9). Warsaw, Poland: RPO.

Bohnert, J. (2000). Allgemeine Vorschriften. In K. Boujong (Ed.), Karlsruber Kommentar zum Gesetz über Ordnungswidrigkeiten [Karlsruber commentary to the law of administrative offenses] (pp. 25-72). Munich, Germany: C. H. Beck.

Bojarski, T. (1990). Przestępstwo a wykroczenie [Crime versus petty offense]. In T. Bojarski (Ed.), Problemy ewolucji prawa karnego [Issues of the evolution of criminal law] (pp. 25-46). Lublin, Poland: Wydawnictwo Uniwersytetu Marii Curie Skłodowskiej. 
Budyn-Kulik, M. (2012). Model ścigania sprawcy wykroczenia w wybranych państwach [Model of prosecution of petty offenders in selected countries]. Studia Iuridica Lublinensia, 17, 65-88.

Budyn-Kulik, M. (2017). Wykroczenia - małe przestępstwa, czy czyny o charakterze administracyjnym [Offences - minor crimes or acts of an administrative nature]. In T. Grzegorczyk \& R. Olszewski (Eds.), Verba volant, scripta manent. Proces karny, prawo karne skarbowe i prawo wykroczeń po zmianach z lat 2015.2016. Ksiega pamiatkowa poświęcona Profesor Monice Zbrojewskiej [Criminal trial, criminal fiscal law and petty offenses law after the changes of $2015-2016$. Memorial book dedicated to Professor Monika Zbrojewska] (pp. 40-54). Warsaw, Poland: Wolters Kluwer Polska.

Cramer, P. (1971). Grundbegriffe des Rechts der Ordnungswidrigkeiten [Basic concepts of the law of administrative offences]. Stuttgart, Germany: W. Kohlhammer.

Danecka, D. (2018). Konwersja odpowiedzialności karnej $w$ administracyjna w prawie polskim [Conversion of criminal liability into administrative liability under Polish law]. Warsaw, Poland: Wolters Kluwer Polska.

Daniluk, P. (2010). Zbieg odpowiedzialności represyjnej za nieopłacenie składek na ubezpieczenia społeczne [Combination of punitive liability for non-payment of social security contributions]. In P. Daniluk \& P. Radziewicz (Eds.), Aktualne problemy konstytucyjne w świetle wniosków, pytan prawnych $i$ skarg konstytucyjnych do Trybunatu Konstytucyjnego [Current constitutional problems in the light of applications, legal questions and constitutional complaints to the Constitutional Court] (pp. 551-558) Warsaw, Poland: Wydawnictwo Sejmowe, https:// doi.org/10.37232/sp.2014.4.8

Daręgowski, J. (1959). Uwagi o postępowaniu i orzecznictwie karno-administracyjnym [Observations on criminal-administrative procedure and jurisprudence]. Palestra, 3/9(21), 19-35.

Dąbrowski, W. F. (1967). Nowe aspekty orzecznictwa karno-administracyjnego [New aspects of criminal-administrative case law]. Ruch Prawniczy, Ekonomiczny i Socjologiczny, 29(1), 89-103.

Dąbrowski, W. F. (1970). Zagadnienia ogólne orzecznictwa karno - administracyjnego w PRL [General issues of penal and administrative jurisprudence in the People's Republic of Poland]. Poznan, Poland: Wydawnictwo Uniwersytetu Adama Mickiewicza.

Domański, G. (1976). Administracyjne kary pieniężne za zanieczyszczenie środowiska [Administrative monetary penalties for environmental pollution]. Przeglad Ustawodawstwa Gospodarczego, 12, 326-333.

Eser, A. (1961). Die Abgrenzung von Straftaten und Ordnungswidrigkeiten [The demarcation between criminal offences and administrative offences]. Würzburg, Germany: Walter Sax.

Filipek, J. (1963). Sankcja w prawie administracyjnym [Sanction in administrative law]. Panstwo i Prawo, 12, 874-875.

Frank, R. (1897). Studien zum Polizeistrafrecht [Studies on police criminal law]. Gießen, Germany: Gießener Universität. 
Frank, R. (1905). Verwaltungsstrafrecht. Mitteilungen der Internationalen Kriminalistischen Vereinigung, 12, 200-220.

Gadecki, B. (2018). Zmiany w zakresie karnoprawnej ochrony zabytków w związku z uchwaleniem ustawy z dnia 22 czerwca 2017 roku o zmianie ustawy o ochronie zabytków i opiece nad zabytkami oraz niektórych innych ustaw [Changes in the criminal law protection of monuments in connection with the enactment of the Act of 22 June 2017 amending the Act on the protection and care of monuments and some other acts]. Santander Culture and Art. Review, 1(4), 81-96, https://doi.org/10.4467/2450050xsnr.18.004.9765

Glaser, S., \& Mogilnicki, A. (1934). Kodeks karny. Komentarz. [Criminal code. Commentary]. Krakow, Poland: Księgarnia Powszechna.

Goldschmidt, J. (1902). Die Verwaltungsstrafrecht [The administrative penal law]. Berlin, Germany: Carl Heymanns Verlag.

Gostyński, Z. (1982). Prawo o wykroczeniach [Law on petty offences]. Katowice, Poland: Wydawnictwo Uniwersytetu śląskiego.

Górski, M. (2007). Odpowiedzialność administracyjna w ochronie środowiska zagadnienia podstawowe [Administrative responsibility in environmental protection - basic issues]. Poznan, Poland: Wolters Kluwer Polska.

Gullikson, M. (2015). Effective sanctions as the one-dimensional limit to the Ne Bis in Idem principle in EU law. In J. Nergelius \& E. Kristofferson (Eds.), Human rights in contemporary European law (pp.141-190). London, UK: Hart Publishing, https://doi.org/10.5040/9781474201414.ch-010

Günther, K. L. (1990). Das Recht der Ordnungswidrigkeiten - Aufbruch zu neuern Ufern? [The law of administrative offences - moving to new shores?]. In K. W. Nörr (Ed.), 40 Jabre Bundesrepublik Deutschland - 40 Jabre. Rechtsentwicklung, Ringvorlesung der Juristischen Fakultät der Universität Tübingen [40 years of Federal Republic of Germany - 40 years. Legal development, lecture series of the Faculty of Law, University of Tübingen] (pp. 381-394). Tübingen, Germany: J. C. B. Mohr (Paul Siebeck), https://doi.org/10.9785/9783504387020-004

Gürtler, F. (2012). Geltungsbereich. In E. Göhler, F. Gürtler \& H. Seitz (Eds.), Gesetz über Ordnungswidrigkeiten [Law on administrative offences] (pp. 11-67). Munich, Germany: C.H. Beck.

Härter, K. (2007). Policeygesetzgebung und Strafrecht: Criminalpolicy Ordnungsdiskurse und Strafjustiz im frühneuzeitlichen Alten Reich [Police law und criminal law: Criminal policy disputes on order and criminal justice in early modern old empire]. In S. Kasper-Biermann \& D. Klippel (Eds.), Kriminalität in Mittelalter und Früber Neuzeit. Soziale, rechtliche, philosophische und literarische Aspekten [Crime in the middle ages and early modern times. Social, legal, philosophical and literary aspects] (pp. 189-210). Wiesbaden, Germany: Harrassowitz Verlag.

Härter, K. (1999). Social control and the enforcement of police ordinances in early modern criminal procedure. In H. Schilling (Ed.), Institutionen, Instrumente und Akteure sozialer Kontrolle und Disziplinierung im frübneuzeitlichen Europe [Institutions, instruments and actors of social control and discipline in early mod- 
ern Europe] (pp. 29-55). Frankfurt, Germany: Vittorio Klostermann Verlag, https://doi.org/10.1017/s002204690151739x

Heine, G. (1999). Unterschiedung zwischen Straftaten und Ordnungswidrigkeiten [Distinction between criminal offences and administrative offences]. Jurisprudencija, 12, 16-27.

Iserzon, E. (1961). Kierunki reformy orzecznictwa karno-administracyjnego [Directions for reform of criminal-administrative case-law]. Państwo i Prawo, 11, 770-780.

Iserzon, E. (1959). Reforma orzecznictwa karno-administracyjnego [Reform of criminal-administrative case-law]. Państwo i Prawo, 8/9, 250-256.

Jaag, T. (2010). Verwaltungsrechtliche Sanktionen, Einführung [Administrative sanctions, introduction]. In I. Häner \& B. Waldmann (Eds.), Verwaltungsstrafrecht und sanktionierendes Verwaltungsrecht [Administrative criminal law and sanctioning administrative law] (pp. 1-18). Zürich-Basel-Genf, Switzerland: Schulthess.

Jakubowska-Hara, J. (2004). Grzywna w prawie wykroczeń. Model ustawowy i praktyka [A fine in the law of offences. Statutory model and practice]. Warsaw, Poland: Europejska Wyższa Szkoła Prawa i Administracji.

Jastrzębski, L. (1956). W sprawie niektórych zagadnień orzecznictwa karno - administracyjnego [On certain issues of criminal and administrative case law]. Nowe Prawo, 1, 99-107.

Jescheck, H. H. (1959). Das deutsche Wirtschaftsstrafrecht [German white-collar crime law]. Juristenzeitung, 15/16, 457-463.

Klaus, M. (2013). Ideał wychowania w Polsce w latach 1945. - 1949. w publicystyce Nowej Szkoły [The ideal of education in Poland between 1945-1949 in the practice of the New School]. Przeglad Pedagogiczny, 1, 77-86.

Kmieciak, Z. (1997). Charakter prawny orzeczeń w sprawach o naruszenie dyscypliny budżetowej a koncepcja sankcji administracyjnej [Legal nature of decisions in budgetary discipline cases and the concept of administrative sanctions]. Glosa, 11, 1-6.

Köstlin, R. (1845). Neue Revision der Grundbegriffe des Criminalrechts [New revision of the basic concepts of criminal law]. Tübngen, Germany: H. Laupp.

Kubicki, L. (1961). Projekt prawa o wykroczeniach [The draft law of petty offences]. Państwo i Prawo, 10, 490-502.

Kulik, M. (2020). Historyczny rozwój prawa administracyjno-karnego w państwach niemieckojęzycznych [Historical development of administrative and criminal law in German-speaking countries]. In P. Daniluk (Ed.), Reforma prawa wykroczeń vol. 2 [Reform of petty offences law vol. 2] (pp. 91-136). Warsaw, Poland: C.H. Beck.

Kulik, M. (2020). Istota wykroczenia na tle istoty przestępstwa i istoty deliktu administracyjnego $\mathrm{w}$ Polsce [The nature of the petty offence against the background of the nature of the crime and the nature of the administrative tort in Poland]. In P. Daniluk (Ed.), Reforma prawa wykroczeń vol. 22 [Reform of petty offences law vol. 2] (pp. 139-181). Warsaw, Poland: C.H. Beck. 
Król-Bogomilska, M. (2012). Z problematyki zbiegu odpowiedzialności karnej i administracyjnej - w świetle orzecznictwa Trybunału Konstytucyjnego [From the problem of coincidence of criminal and administrative liability - in the light of the jurisprudence of the Constitutional Tribunal]. In M. Płatek \& M. Dziewanowska (Eds.), Wina i kara. Ksiega pamięci Profesor Genowefy Rejman [Guilt and punishment. Book in memory of professor Genowefa Rejman] (pp. 5776). Warsaw, Poland: Wydawnictwo Uniwersytetu Warszawskiego.

Kruk, E. (2009). Przymus administracyjny [Administrative constraint]. Administracja: Teoria, Dydaktyka, Praktyka, 2(15), 107-131.

Kruk, E. (2013). Sankcja administracyjna [Administrative sanction]. Lublin, Poland: Wydawnictwo Uniwersytetu Marii Curie-Skłodowskiej.

Krümpelmann, J. (1966). Die Bagatelldelikte [The Petty Crimes]. Berlin, Germany: Duncker \& Humblot.

Kwaśnicka, K. (2011). Odpowiedzialność administracyjna w prawie ochrony środowiska [Administrative liability in environmental law]. Warsaw, Poland: Wolters Kluwer Polska.

Lenieli, L. (1961). Określenie wykroczenia w projekcie prawa o wykroczeniach [Definition of a petty offence in the draft law on petty offences]. Zagadnienia Karno-Administracyjne, 2, 20.

Lewiński, J. (1977). Ksztattowanie stosowanej przez kolegia do spraw wykroczeń polityki karania przez organy nadzoru [Shaping the supervisory sentencing policy of the colleges of offences]. Paper presented at Materiały na Sesję Popularno-Naukową z okazji XXV-lecia kolegiów do spraw wykroczeń 21.IV.1977 Warszawa, Wydawnictwo Ministerstwa Spraw Wewnętrznych, pp. 1-10.

Lewicki, M. (2002). Pojęcie sankcji prawnej w prawie administracyjnym [The concept of legal sanction in administrative law]. Państwo i Prawo, 8, 63-75.

Litwin, J. (1955). Przedmowa [Introduction]. In R. Rajkowski (Ed.), Prawo karno-administracyjne Polski Ludowej. Zarys części ogólnej i postępowania [Criminal-administrative law of the People's Republic of Poland. Outline of the general part and proceedings] (pp. 2-7). Warsaw, Poland: Wydawnictwo Prawnicze.

Lityński, A. (2010). Prawo Rosji i ZSRR 1917-1991, czyli bistoria wszechzwiazkowego komunistycznego prawa (bolszewikow) [The law of Russia and the USSR 1917-1991, or the bistory of the all-union communist law (Bolsheviks)]. Warsaw, Poland: C. H. Beck.

Lityński, A. (1991). Wydziat karny Komisji Kodyfikacyjnej II Rzeczypospolitej. Dzieje prac nad czéścia ogólna kodeksu karnego [The penal department of the codification committee of the second Republic of Poland. The bistory of works on the general part of the penal code]. Katowice, Poland: Wydawnictwo Uniwersytetu Ślaskiego.

Lo Schiavo, G. (2018), The principle of ne bis in idem and the application of criminal sanctions: Of scope and restrictions. European Constitutional Law Review, 14, 644-663.

Longchamps, F. (1967). Problemy pogranicza prawa administracyjnego [Problems on the borderline of administrative law]. Studia Prawnicze, 12. 
Luchtman, M (2018), The ECJ's recent case law on ne bis in idem: Implications for law enforcement in a shared legal order. Common Market Law Review, 55(6), 1717-1750.

Łysko, M. (2020). Operation of retraining minor offences into misdemeanours in the people's Poland. Studia Iuridica Lublinensia, 29(5), 201-203, https://doi. org/10.17951/sil.2020.29.5.197-214

Łysko, M. (2011). Orzecznictwo karno-administracyjne w walce $\mathrm{z}$ alkoholizmem $\mathrm{w}$ okresie gomułkowskim [Penal-administrative jurisprudence in the fight against alcoholism in the Gomułka period]. Z Dziejów Prawa, 4(12), 249-281.

Łysko, M. (2016). Prace nad kodyfikacja materialnego prawa wykroczeń w Polsce Ludowej (1960. - 1971.) [Work on the codification of substantive law on petty offence in People's Poland (1960. - 1971.)]. Bialystok, Poland: Temida 2, https://doi. org/10.14746/cph.2017.2.19

Łysko, M. (2017). Projekt ustawy o ustroju kolegiów do spraw wykroczeń z 1970 r. w ocenie uczestników dyskusji społecznej [The draft Act on the establishment of the colleges of petty offences 1970 as assessed by participants in the public discussion]. Miscellanea Historico-Iuridica, 15(1), 184- 203, https://doi. org/10.15290/mhi.2016.15.01.10

Łysko, M. (2015). Udział przedstawicieli nauki w pracach nad kodyfikacją materialnego prawa wykroczeń w Polsce Ludowej [Participation of scientific representatives in the work on the codification of substantive law of petty offences in the People's Republic of Poland]. Czasopismo Prawno-Historyczne, 67(1), 129-167, https://doi.org/10.14746/cph.2015.68.1.08

Makarewicz, J. (1920), Granice ustawy karnej [Boundaries of criminal law]. Przeglad Prawa i Administracji, 4/6,92-97.

Makarewicz, J. (1920). Powrotna fala [The return wave]. Ruch Prawny, Ekonomiczny $i$ Socjologiczny, 4, 475-501.

Makarewicz, J. (1924). Prawo karne [Criminal law]. Lviv-Warsaw, Poland: Książnica Polska.

Makowski, W. (1937). Kodeks karny. Komentarz [Criminal Code. Commentary]. Warsaw, Poland: F. Hoesik.

Malanowski, J. (2009). Pojęcie i koncepcje odpowiedzialności administracyjnoprawnej [Understanding and concepts of administrative law liability]. In M. Wierzbowski, J. Jagielski, A. Wiktorowska \& E. Stefańska (Eds.), Wspótczesne zagadnienia prawa $i$ procedury administracyjnej. Ksiega jubileuszowa dedykowana Prof. zw. dr. hab. Jackowi M. Langowi [Contemporary issues in law and administrative procedure. A jubilee book dedicated to Prof. $z w$. dr. hab. Jacek M. Lang] (pp. 135-150). Warsaw, Poland: Wolters Kluwer Polska, https://doi. org/10.18778/8088-187-7.03

Marek, A. (1967). Istota i zasady odpowiedzialności za wykroczenia - na tle ustawy o przekazaniu niektórych drobnych przestępstw do orzecznictwa karno - administracyjnego [The nature and principles of liability for petty offences - against the background of the Act on transferring certain minor offences to criminal and administrative jurisdiction]. Palestra, 5, 81-90. 
Marek, A. (2010). Prawo wykroczeń [The law on petty offences], Warsaw, Poland: C. H. Beck.

Marek, A. (1996). Proponowany model prawa wykroczeń i orzecznictwa w sprawach o wykroczenia na tle standardów europejskich [Proposed model of petty offence law and jurisprudence against the background of European standard]. In T. Bojarski, M. Mozgawa \& J. Szumski (Eds.), Rozwój polskiego prawa wykroczeń [Development of Polish petty offence law] (pp. 26-27). Lublin, Poland: Wydawnictwo marii Curie-Skłodowskiej.

Marek, A. (2010). System Prawa Karnego [The concept of criminal law and petty offence law]. In A. Marek (Ed.), System Prawa Karnego. Zagadnienia ogólne vol. 1 [Criminal law system. General issues], (pp. 1-25) Warsaw, Poland: C. H. Beck.

Mattes, H. (1970). Die Problematik der Umwandlung des Verkehrsübertretungen in Ordnungswidrigleiten [The problem of converting traffic violations into administrative offences]. Zeitschrift für die gesamte Strafrechtswissenschaft, 82, 25-39, https://doi.org/10.1515/zstw.1970.82.1.25

Michór, A. (2009). Odpowiedzialność administracyjna w obrocie instrumentami finansowymi [Administrative liability in trading in financial instruments]. Warsaw, Poland: ABC.

Mieńszagin, W., \& Wyszyńska, Z. (1953). Radzieckie prawo karne [Soviet criminal law]. Warsaw, Poland: Wydawnictwo Ministerstwa Obrony Narodowej.

Mitsch, W. (1995). Recht der Ordnungswidrigkeiten [Law on administrative offences]. Berlin, Germany: Springer.

Mozgawa, M., \& Kulik, M. (2016). Wybrane zagadnienia z zakresu wzajemnego stosunku odpowiedzialności karnej i administracyjnej [Selected issues in the mutual relationship between criminal and administrative liability]. Ius Novum, 3, 31-63.

Müller, D. (2018). Gesetz über Ordnungswidrigkeiten [Law on administrative offences]. Neuwied, Germany: C. H. Beck.

Müller-Dalhoff, G. (1993). Zur Abgrenzung von Straftaten und Ordnungswidrigkeiten am Beispiel des Lebensmittelsrechts [On the demarcation of criminal offences and administrative offences using the example of food law]. Freiburg, Germany: Hochschulverlag.

Niggli, M. A., \& Maeder, S. (2011). Was schützt eigentlich Strafrecht (und schütz es es überhaupt etwas)? [What does criminal law actually protect (and does it protect anything at all)?]. Aktuelle Juristische Praxis, 4(20), 47-500.

Nowicki, D. K., \& Peszkowski, S. (2016). Kilka uwag o szczególnym charakterze administracyjnych kar pieniężnych [Some remarks on the specific nature of administrative fines]. In M. Błachucki (Ed.), Administracyjne kary pieniężne $w$ demokratycznym państwie prawa [Administrative pecuniary penalties in a democratic state under the rule of law] (pp. 11-27). Warsaw, Poland: Wydawictwo rzecznika Praw Obywatelskich.

Ohana, D. (2014). Administrative penalties in the Rechtsstaat: On the emergence of the ordnungswidrigkeit sanctioning system in post-war Germany. University of Toronto Law Journal, 64(2), 243-290, https://doi.org/10.3138/utlj.0517 
Projekt kodeksu karnego, Częéć ogólna, Wprowadzenie [Draft penal code, general part, introduction]. Warsaw 1966, p. 3., Wydawnictwo Prawnicze.

Radecki, W. (2019) Delikty administracyjne [Administrative offences]. In P. Daniluk (Ed.), Reforma prawa wykroczeń, 1, 30-49.

Radecki, W. (2014). Dezintegracja polskiego prawa penalnego [Disintegration of Polish Penal Law]. Prokuratura i Prawo, 9, 5-27.

Radecki, W. (1994). Kilka uwag o zastępowaniu odpowiedzialności karnej odpowiedzialnościa administracyjna [Some remarks on the substitution of criminal liability for administrative liability]. In M. Bojarski (Ed.), Wspótczesne problemy nauk penalnych. Zagadnienia wybrane [Contemporary problems of penal sciences. Selected issues] (pp. 13-22). Wroclaw, Poland: Wydawnictwo Uniwersytetu Wrocławskiego.

Radecki, W. (2009). Polskie prawo karne środowiska - próba spojrzenia syntetycznego [Polish Environmental Criminal Law - An attempt at a synthetic view]. Ius Novum, 1, 70-94.

Rajkowski, R. (1955). Prawo karno-administracyjne Polski Ludowej. Zarys części ogólnej i postępowania [Criminal-administrative law of the People's Republic of Poland. Outline of the general part and proceedings]. Warsaw, Poland: Wydawnictwo Prawnicze.

Rappaport, E. S. (1919). Zagadnienie kodyfikacji wykroczeń w ustawodawstwie polskim (autoreferat sprawozdawczy) [The issue of codification of offences in Polish legislation (self-reporting).]. Gazeta Sadowa Warszawska, 9, 334-336.

Rebmann, K., Roth, W., \& Hermann, S. (1996). Gesetz über Ordnungswidrigkeiten. Kommentar [Code of administrative offences. Comment]. Stuttgart, Germany: C. H. Beck.

Rybicki, Z., \& Sobczak, K. (1957). O niektórych zagadnieniach udziału obywateli w orzecznictwie karno-administracyjnym [On some issues of citizen participation in criminal and administrative decisions]. Państwo i Prawo, 4, 39-55.

Rybicki, Z. (1956). W sprawie niektórych zagadnień orzecznictwa karno-administracyjnego [On certain issues in criminal-administrative case law]. Nowe Prawo, 3, 87-95.

Salem, M. (2009). Die Ordnungswidrigkeit im Straßenverkebr [The administrative offence in road traffic]. Nordstadt, Germany: C. H. Beck.

Schmidt, E. (Oktober, 1949). Das Gesetz zur Vereinfachung des Wirtschaftsstrafrechts [The Act to simplify commercial criminal law]. Süddeutsche Juristenzeitung. Retrieved from https://www.jstor.org/stable/20801328

Schmidt, E. (Oktober, 1948). Rechtsnot im Wirtschaftsstrafrecht und ihre Überwindung [Legal emergency in economic criminal law and its overcoming]. Süddeutsche Juristenzeitung. Retrieved from https://www.jstor.org/stable/23322740

Schmidt, E. (1948). Zur Anwendung des Kontrollratsgesetzes [On the application of the Control Council Law]. Deutsche Richter Zeitung, 50, 412-415.

Schwander, V. (1952). Das schweizerische Strafgesetzbuch [The Swiss penal code]. Zürich, Switzerland: Polygraphischer Verlag. 
Skupiński, J. (1974). Model polskiego prawa o wykroczeniach [The model of Polish law of petty offenses]. Wroclaw-Warsaw-Cracow-Gdansk: Ossolineum.

Skupiński, J. (2003). Odpowiedzialność podmiotów zbiorowych na tle polskiej ustawy z dnia 28 października 2002 r. (próba zarysu problematyki). [Liability of collective entities against the background of the Polish Act of 28 October 2002 (attempt to outline the issues)]. In M. Płachta (Ed.), Aktualne problemy prawa i procesu karnego. Ksiega ofiarowana profesorowi Janowi Grajewskiemu [The contemporary issues of criminal law and criminal proceedings. A book dedicated to Professor Jan Grajewski] (pp. 360-373). Gdansk, Poland: Wydawnistwo Uniwersytetu Gdańskiego.

Stahl, M. (2011). Sankcje administracyjne - problemy węzłowe [Administrative sanctions - knotty issues]. In M. Stahl, R. Lewicka \& M. Lewicki (Eds.), Sankcje administracyjne - blaski i cienie [Administrative sanctions - bighlights and shadows] (pp. 17-30). Warsaw, Poland: Wolters Kluwer Polska.

Starzyński, P. (2013). Idealny zbieg odpowiedzialności karnej i administracyjnej - standard sankcji karnych i administracyjnych [The perfect concurrence of criminal and administrative liability - Standard of criminal and administrative sanctions]. In S. Pikulski \& M. Romańczuk-Grącka (Eds.), Granice kryminalizacji $i$ penalizacji [Limits of criminalisation and penalisation] (pp. 458-472). Olsztyn, Poland: ElSet.

Stefaniuk, M. (2009). Działanie administracji publicznej w ujęciu nauk administracyjnych [The operation of public administration as seen from the perspective of administrative science]. Lublin, Poland: Wydawnictwo Uniwersytetu Marii Curie-Skłodowskiej.

Stelmasiak, J. (1993). Odpowiedzialność prawna w ochronie środowiska. Zagadnienia podstawowe [Legal responsibility in environmental protection. Basic issues]. Annales UMCS. Sectio G. Ius, 11, 199-211.

Stankiewicz, R. (2017). Administrative Sanctions as a Manifestation of State Coercion. Wroctawskie Studia Erazmiańskie, (11), 268- 279.

Sziszow, O. (1961). O rozgraniczeniu przestępstw i wykroczeń administracyjnych $\mathrm{w}$ prawie radzieckim [On the delimitation of administrative offences in Soviet law]. Zagadnienia Karno-Administracyjne, 5, 49-62.

Szumiło-Kulczycka, D. (2004). Prawo administracyjno-karne [Administrative criminal law]. Krakow, Poland: Zakamycze.

Szydło, M. (2003). Charakter i struktura prawna administracyjnych kar pieniężnych [Nature and legal structure of administrative fines]. Studia Prawnicze, 4, 123-150.

Theisen, R. D., \& Vesper, C. (2010). Ordnungswidrigkeitenrecht [Law on administrative offenses]. Witten, Germany: Bernhardt, Horst.

Ušak, M. (2010). Kary pieniężne i kary finansowe w ramach nadzoru bankowego [Financial penalties and fines under banking supervision]. In E. Fojcik-Mastalska \& E. Rutkowska-Tomaszewska (Eds.), Bezpieczeństwo rynku finansowego [Financial market security]. Wroclaw, Poland: Legal and Economic Digital Library. 
Vachev, V. (2016). Racjonalizacja prawa wykroczeń - potrzebna jest reforma [Rationalisation of law of petty offences - reform needed]. In M. Kolendowska-Matejczuk \& V. Vachev (Eds.), Wezłowe problemy prawa wykroczeń - czy potrzebna jest reforma? [The knotty problems of law of petty offences - is reform needed?]. Warsaw, Poland: Wydawnictwo Biura Rzecznika Praw Obywatelskich, https://doi.org/10.31743/spw.4786

von Feuerbach, P. J. A. (1801). Lebrbuch des gemeinen in Deutschland geltenden peinlichen Rechts [Handbook on the common punitive law applicable in Germany]. Giesen, Germany: Georg Friedrich Hoyer.

von Feuerbach, P. J. A. (1822). Ueber Polizeistraf-Gesetzbung überhaupt und den zweiten Theil eines "Entwurfs des Strafgesetzbuchs" [On policy penal law and the second part of a "Draft of the Criminal Code"]. Munich, Germany: Akademie Verlag, https://doi.org/10.1515/9783050065939-043

Wierzbowski, M. (2005). Opinia o projekcie ustawy "Przepisy ogólne prawa administracyjnego" [Opinion on the draft law "General provisions of administrative law"]. Retrieved from http://www.rpo.gov.pl/pliki/12664874740.pdf

Wincenciak, M. (2008). Sankcje w prawie administracyjnym $i$ procedura ich wymierzania [Sanctions in administrative law and the procedure of their imposition]. Warsaw, Poland: Wolters Kluwer Polska.

Wolter, W. (1973). Nauka o przestepstwie [The science of crime]. Warsaw, Poland: Państwowe Wydawnictwo Naukowe.

Wolter, W. (1947). Prawo karne. Zarys wyktadu systematycznego [Criminal Law. Outline of a systematic lecture]. Warsaw, Poland: Gebethner i Wolff.

Wróbel, W. (2011). Zakaz podwójnej karalności i zasada ne bis in idem w obszarze przestępstw, wykroczeń oraz deliktów administracyjnych - wybrane zagadnienia [Prohibition of double criminality and the ne bis in idem principle in the area of crimes, petty offences and administrative torts - selected issues]. In J. Godyń, M. Hudzik \& L.K. Paprzycki (Eds.), Zagadnienia prawa dowodowego (pp. 130-149). Warsaw, Poland: Wydwnictwo Sądu Najwyższego.

Zimmermann, M. (1956). Odpowiedzialnośc administracyjna [Adminsitrative responsibility] In M. Jaroszyński, M. Zimmermann \& W. Brzeziński (Eds.), Polskie prawo administracyjne. Zarys części ogólnej [Polish administrative law. Outline of the general part] (pp. 400-420). Warsaw, Poland: Państwowe Wydawnictwo Naukowe.

\section{Legal Sources}

Act amending the Act of Administrative Procedure and certain other acts, Journal of Laws of 2017, item 935.

Act of 22 June 2017, amending the Act on the protection and care of monuments and some other acts, Journal of Laws, item 1595.

Act of 5 December 2008, on prevention and control of infections and infectious diseases in humans, Journal of Laws, no 234, item 1570. 
Decree on securing the rational and economical use of electricity and heat, Journal of Laws No. 9, item 26.

Law on criminal- administrative judgments, Journal of Laws No. 66, item 454.

Law on criminal-administrative proceedings, Journal of Laws 38, item 265.

Law on Petty Offences, Journal of Laws 60, item 572.

Law on the transfer of certain minor offenses as petty offenses to criminal-administrative judgments, Journal of Laws No. 23, item 149.

\section{Case-Law}

Judgment of the Constitutional Tribunal, K 17/97, Warsaw, 29. 4. 1998

Judgment of the Constitutional Tribunal, P 26/06, Warsaw, 15. 4. 2008

Judgment of the Constitutional Tribunal, P 29/09, Warsaw, 18. 11. 2010

Judgment of the ECtHR, 5100/71, Strasbourg, 8. 6. 1976

Judgment of the ECtHR 7819/77, Strasbourg, 10. 2. 1984

Judgment of the ECtHR 9912/82, Strasbourg, 28. 6. 1987

Judgment of the ECtHR, 9912/82, Strasbourg, 25. 8. 1987

Judgment of the ECtHR 11034/84, Strasbourg, 22. 5. 1990

Judgment of the ECtHR, 18996/91, Strasbourg, 24. 8. 1997

Judgment of the Supreme Court, I KZP 27/08, Warsaw, 17. 12. 2008

Judgment of the ECtHR 14939/03, Strasbourg, 10. 2. 2009

Judgment of the ECtHR (Appl. Nos. 24130/11 and 29758/11), Strasbourg, 16.

11. 2016

PETTY OFFENCES IN POLAND BETWEEN CRIMINAL LAW AND ADMINISTRATIVE LAW

\section{Summary}

The legislator may have different views on the role and position of petty offence law in the contemporary legal order. They are often extreme. This ranges from treating petty offence law as a variety of criminal law, to simply accepting that it is notbing more than law of order. What is more, it often happens that adopting a specific concept requires quite different functions and goals of petty offence law. For these reasons, the fate of petty offence law varies. However, this does not affect the essence of the relationship between petty offence law and both criminal and administrative law, which is relatively large. With this in mind, the authors 
made efforts to synthetically yet comprehensively present the essential features of Polish petty offence law and its evolution from the 1920-30s to the present day. It is worth emphasising once again that the current shape of petty offence law is the result of long-term changes which resulted in a number of effects, not always desired. Moreover, as part of the conclusions, an attempt was made to formulate a prognosis for the development of this branch of law and the direction in which it will probably go.

Keywords: petty offences, relationship between petty offence, crime and administrative tort, evolution of Polish petty offence law

\section{SITNI PREKRŠAJI U POLJSKOJ IZMEĐU KAZNENOG I UPRAVNOG PRAVA}

\section{Sažetak}

Zakonodavac može imati različite poglede na ulogu i položaj prava sitnih prekršaja u suvremenome pravnom poretku, od onib koji pravo sitnih prekršaja smatraju vrstom kaznenog prava do onib koji jednostavno pribvaćaju da je ono tek pravo očuvanja reda. Štoviše, često se dogada da pribvaćanje odredenog koncepta zabtijeva specifično poimanje uloge i položaja prava sitnib prekršaja. Zbog tib je razloga sudbina prava sitnih prekršaja promjenjiva. Ipak, to sve ne utječe na samu bit odnosa prava sitnih prekršaja s kaznenim i upravnim pravom. S tim na umu, autori rada predstavljaju bitne karakteristike poljskog prava sitnih prekršaja na sintetičan i sveobubvatan način kao i njegovu evoluciju od 20-ih godina 20. stoljeća do današnjib dana. Potrebno je još jedanput naglasiti da je trenutačno stanje prava sitnih prekršaja rezultat dugotrajnih promjena koje su proizvele mnoge učinke, ne uvijek namjeravane. Štoviše, u zaključku autori pokušavaju formulirati prognozu daljnjeg razvoja te grane prava i smjera u kojem će on vjerojatno ići.

Ključne riječi: sitni prekršaji, odnos sitnog prekršaja, kaznenog djela $i$ upravnog delikta, evolucija poljskog prava sitnib prekršaja 